\title{
TRANSFER TEKNOLOGI BIOFLOK PADA BUDI DAYA IKAN LELE : UPAYA PENINGKATAN PRODUKTIVITAS USAHA YANG RAMAH LINGKUNGAN
}

\author{
Transfer Of Bioflok Technology In Lele Fish Culture: Effort Enhancement Of Produc- \\ tivity In Environmentally Friendly Business
}

\author{
Taufik Budhi Pramono'), Sri Marnani ${ }^{1)}$, Sukanto $^{2)}$. \\ ${ }^{1}$ Fakultas Perikanan dan Ilmu Kelautan, Universitas Jenderal Soedirman, \\ 2 Fakultas Biologi, Universitas Jenderal Soedirman \\ email: tb1pram@yahoo.com
}

\begin{abstract}
ABSTRAK
Masalah utama yang dihadapi oleh para pembudi daya ikan lele dumbo saat ini adalah inefisiensi input produksi yaitu pemanfaatan pakan. Produktivitas dan margin keuntungan yang dihasilkannya sangat rendah. Permasalahan lain dari inefisiensi pakan yang muncul yaitu sisa pakan di dasar kolam dan pada akhirnya dapat menyebabkan racun bahkan Kematian pada ikan dan kegagalan produksi. Salah satu upaya yang perlu dilakukan adalah merekayasa dengan teknologi bioflok. Teknologi Bioflok pada budi daya ikan lele sangat penting ditransfer kepada masyarakat pembudi daya ikan. Tujuan kegiatan ini adalah untuk meningkatkan pengetahuan, keterampilan dan pendapatan masyarakat pembudi daya ikan. Metode yang dilakukan yaitu dengan alih teknologi, demonstrasi plot dan penerapan IPTEK. Hasil menunjukkan dengan masyarakat pembudi daya antusias dan terampil dalam penguasaan teknologi bioflok. Produktivitasnya mencapai $568 \mathrm{Kg}$ dengan kepadatan tinggi dan FCR mencapai 0,7 serta keuntungan bersih mencapai Rp. 2.850.000,-.
\end{abstract}

Kata kunci: lele, bioflok, teknologi

\section{ABSTRACT}

The main problem caused by African catfish farmers is the input production inefficiency, namely the use of feed. The productivity and profit margins it produces are very low. Another problem with feed inefficiency that arises is the remaining feed at the bottom of the pond and can eventually cause toxins and even death in fish and production failure. One effort that needs to be done is to engineer biofloc technology. Biofloc technology in catfish farming is very important to be transferred to the fish farmers community. The purpose of this activity is to improve the knowledge, skills, and income of fish farmers. The method used is technology transfer, plot demonstration, and implementation of science and technology. The results show that the farming community is enthusiastic and trained in mastering biofloc technology. Its productivity reaches 568 $K g$ with high density and FCR reaches 0.7 and net profit reaches Rp. 2,850,000.

Keywords: catfish, biofloc, technology

\section{PENDAHULUAN}

Ikan lele merupakan salah satu ikan air tawar yang memiliki nilai ekonomis penting di masyarakat. Hal ini ditandai banyaknya masyarakat yang membudi dayakan dan mengkonsumsinya untuk kebutuhan protein hewani keluarga yang relatif murah. Namun demikian, para 
pembudi daya ikan sering mengalami kerugian karena biaya produksi terutama harga pakan yang cenderung terus meningkat. Pakan merupakan faktor produksi terbesar dalam usaha budi daya ikan.

Tingkat kematian yang tinggi sering ditemui oleh para pembudi daya ikan lele Mina Rawa Mas dan Mina Lancar di Kabupaten Purbalingga. Masalah yang nyata pada usaha budi daya ikan lele adalah cepatnya terakumulasi sisa pakan, bahan organik, dan senyawa toksin. Pakan biasanya hanya dipandang sebagai pemacu pertumbuhan dan bukan sumber polutan terbesar dalam budi daya, karena ikan hanya mampu memanfaatkan protein pakan sekitar 25-30\%. Limbah budi daya ikan berasal dari sisa pakan yang tidak termakan oleh ikan maupun sisa metabolisme dari ikan (Sarwono, \& Agustina, 2002). Limbah ini banyak mengandung amonia yang sangat beracun bagi organisme budi daya. Sisanya dikeluarkan dari tubuh ikan dan umumnya terkumpul dalam air (Affandi, 2004). Lebih lanjut Akumulasi sisa pakan dan hasil metabolisme ikan yang terjadi pada sistem budi daya, menyebabkan tingginya kadar amonium dan nitrit yang berpengaruh pada daya tahan tubuh ikan (Durborow et al., 1997a) dalam (Hernawati, \& Suantika,
2007; Ekasari, 2009). Daya tahan tubuh ikan yang melemah akan menimbulkan stres dan penyakit sehingga menimbulkan kematian.

Salah satu cara yang bisa digunakan untuk menanggulangi limbah perikanan berupa amonia ialah sistem bioflok. Penggunaan sistem bioflok merupakan satu cara pengelolaan kualitas air dengan memanfaatkan aktivitas mikroba untuk menguraikan amonium (hasil limbah pakan dan feses ikan) menjadi protein mikrobial. Hasil dari penguraian amonium dapat dimanfaatkan menjadi pakan bagi ikan yang dibudi dayakan (Avnimelech , \& Kochba, 2009).

Teknologi bioflok telah banyak diterapkan untuk budi daya ikan atau udang di daerah USA dan Israel. Perkembangan teknologi bioflok di kolam ditunjuk sebagai potensi efektif sumber makanan untuk ikan nila, dan mungkin ikan lainnya. Kontribusi pakan bioflok dalam kolam diuji memberikan kontribusi hampir 50\% dari kebutuhan protein ikan. Penyimpanan potensi pakan dan dinamika air kolam dapat dengan mudah ditentukan di lapangan melalui pemantauan volume flok. Ikan yang tumbuh di kolam BFT tidak terburu-buru menambahkan pelet sebagai pakan tambahan, karena di kolam terdapat gumpalan sebagai pakan, pakan potensial 
yang tersedia 24 jam per hari (Anvimelech Y, 2007).

Permasalahan yang dihadapi oleh kedua kelompok pembudi daya ikan perlu mendapat prioritas penanganan. Pendekatan yang dilakukan yaitu (1) efisiensi biaya produksi dari pakan yang cenderung terus meningkat; (2) teknologi budi daya yang masih rendah sehingga produksi dan keuntungannya masih belum memenuhi pemenuhan kebutuhan pasar dan kelayakan usaha.

Tujuan dari kegiatan ipteks bagi masyarakat pembudi daya ikan ini antara lain adalah untuk : (1) meningkatkan pengetahuan pembudi daya ikan tentang budi daya ikan lele system bioflok yang efisien dan lestari (2) meningkatkan keterampilan pembudi daya ikan tentang teknologi dan teknik pemeliharaan lele dengan system bioflok (3) meningkatkan Produktivitas dan keuntungan usaha budi daya lele dengan system bioflok.

\section{METODE KEGIATAN}

Kegiatan ini diawali dengan kegiatan alih teknologi. Alih teknologi dimaksudkan untuk meningkatkan pengetahuan peserta tentang teknologi bioflok pada budi daya ikan lele. Metode kegiatan yang diterapkan adalah ceramah dan diskusi dengan media alih informasi yang interaktif (LCD Proyektor) dan berlangsung dua arah. Metode ini merupakan inisiasi program dengan harapan, industri mitra mempunyai pengetahuan dasar. $\mathrm{Pa}-$ da kegiatan ini kepada para peserta diberikan makalah tentang dua hal yaitu "Teknik Produksi Bioflok", Teknik Pemanfaatan bakterial dan "Manajemen Pemberian Pakan dengan sistem bioflok. Untuk mengetahui tingkat pemahaman peserta tentang alih teknologi yang diberikan, tolok ukur yang digunakan adalah kuesioner yang akan diberikan sebelum (pro Test) dan sesudah (Post Test) alih teknologi dilaksanakan.

Kegiatan selanjutnya yaitu pelatihan dilengkapi dengan demonstrasi Farm (demfarm) teknik produksi bioflok dengan menggunakan bakteri, tetes gula dan pati. Peserta langsung dilibatkan dalam proses pembuatan kolam, proses persiapan media flok dan pemeliharaan yang baik. Kegiatan ini bertujuan meningkatkan keterampilan teknik produksi bioflok tersebut. Tolok ukur keberhasilan program dilakukan adalah dengan melihat kemampuan peserta dalam pengusaaan teknologi produksi bioflok membandingkan hasil peserta dengan yang telah dipersiapkan oleh tim.

Kegiatan penerapan IPTEK juga diberikan demonstration plot (demplot) 
yaitu dengan membagi peserta dalam 2 (dua) kelompok baik industri mitra Mina Rawa Mas dan Mina Lancar untuk langsung melakukan produksi bioflok seperti yang telah diajarkan melalui alih teknologi, pelatihan dan percontohan. Kegiatan ini dilakukan dengan memberikan kesempatan kepada peserta untuk mempraktekkan langsung sebagai bentuk kegiatan atau usaha ekonomi yang baru serta menunjang usaha budi daya. Peserta diberikan modal awal dalam bentuk peralatan dan bahan yang dibutuhkan untuk selama 1 (satu) siklus produksi. Untuk mengetahui kemampuan peserta dalam praktek usaha budi daya ikan dalam kegiatan ekonomi baru, tolok ukur yang digunakan adalah menghitung selisih penerimaan dan biaya produksi.

\section{HASIL DAN PEMBAHASAN} Tanggapan Masyarakat

Kegiatan budi daya lele dengan sistem bioflok bagi kelompok pembudi daya ikan Mina Lancar dan Rawa Mas merupakan suatu hal yang sangat baru bagi mereka. Budi daya ikan lele yang biasa dilakukan oleh kedua kelompok tersebut masih konvensional. Oleh karenanya diberikan alih teknologi baik dari prinsip, proses dan teknik.
Hasil evaluasi pro dan Post Test terlihat untuk kelompok pembudi daya ikan Mina Lancar masih kurang pengetahuannya yang tercermin dari hasil pre test yaitu 50. Namun setelah diberikan alih teknologi pengetahuannya bertambah menjadi 65. Sedangkan kelompok pembudi daya ikan Rawa Mas nilai awal sebesar 60 dan setelah alih teknologi menjadi 75. Perbedaan nilai antara dua kelompok ini karena beberapa anggota Mina Rawa Mas telah mengetahui informasi teknologi bioflok melalui studi banding yang difasilitasi oleh pihak Dinas Perikanan dan Peternakan Kabupaten Purbalingga.

Selama pelaksanaan kegiatan alih teknologi, peserta sangat antusias dalam bertanya . Hal ini mengindikasikan bahwa masyarakat pembudi daya ikan terdorong ingin mengetahui teknologi yang disampaikan dan kemungkinan untuk dikembangkan dalam usahanya. Selain itu, pasca kegiatan IbM ini masyarakat sasaran saat ini menambah unit kolam budi daya dan menerapkan teknologi bioflok dalam usahanya.

\section{Produktivitas}

Produktivitas merupakan salah satu tujuan dari kegiatan IbM ini. Salah satu pendekatan adalah dengan melakukan kegiatan demplot. Demplot dilakukan se- 
bagai upaya pengembangan model pembelajaran dan percontohan bagi masyarakat pembudi daya ikan.

Pelaksanaan demplot dilakukan langsung oleh masyarakat sasaran baik dari persiapan wadah dan media air, pemeliharaan dan pemberian pakan dengan didampingi oleh tim pelaksana.

Dalam pelaksanaan terlihat masyarakat sasaran antusias dan mulai terampil serta memahami secara langsung antara teori dan praktek.

Hasil demplot yang dilakukan oleh kedua kelompok pembudi daya ikan menunjukkan hasil yang cukup baik. Pada kegiatan ini juga terlihat hasil produksinya sangat berbeda nyata dari hasil produksi serta keuntungan ekonomi yang biasa mereka lakukan. Tercatat dari nilai FCR mampu mencapai 0,70 dan 0,98. Nilai FCR ini berarti total pakan yang diberikan sebesar $0,7 \mathrm{Kg}$ mampu menjadi $1 \mathrm{Kg}$ daging. Rata-rata FCR dari budi daya konvensional berkisar antara 1,5-2. Artinya transfer atau alih teknologi dan demplot teknologi bioflok ini mampu memberikan efisiensi input produksi utamanya biaya pakan. Pakan merupakan komponen biaya terbesar dari usaha budi daya hingga mencapai 60-70\%.

Produktivitas biomassa ikan hasil pemeliharaan antara budi daya lele system bioflok dan konvensional juga jauh berbeda (Tabel 1).

Tabel 1. Produktivitas Budi daya Lele bioflok dan konvensional

\begin{tabular}{llll}
\hline Kondisi & Satuan & Biofloc & $\begin{array}{l}\text { Konven- } \\
\text { sional }\end{array}$ \\
\hline $\begin{array}{l}\text { Stocking } \\
\text { Number }\end{array}$ & pcs (bibit) 4.000 & 1.000 \\
$\begin{array}{l}\text { Harvest } \\
\text { Number }\end{array}$ & pcs (ekor) & 454.400 & 85.000 \\
$\begin{array}{l}\text { Total } \\
\text { Harvest }\end{array}$ & Kilograms 568 & 102 \\
\hline
\end{tabular}

Berdasarkan hasil demplot pada Tabel 1 terlihat dengan penerapan bioflok kepadatan ikan dapat dioptimalkan dan hasilnya bisa maksimal hingga mencapai $568 \mathrm{Kg}$ dibandingkan secara konvensional yang hanya mencapai $102 \mathrm{Kg}$.

Capaian lain yang dapat dilihat dari penerapan teknologi bioflok ini perolehan pendapatan kotor (gross revenue) dan pendapatan bersih (nett income) Tabel 2 . Tercatat pendapatan kotor dari penerapan teknologi bioflok mencapai 6,82 juta sedangkan konvensional hanya mencapai 1,22 juta. Demikian pula pendapatan bersih yang diperoleh dari penerapan teknologi bioflok mencapai 2,85 juta dengan prosentase profit $72 \%$.

Tabel 2 Analisis Ekonomi Budi daya Lele Bioflok dan Konvensional

\begin{tabular}{lll}
\hline Revenue & Biofloc Konven- \\
\hline
\end{tabular}




\begin{tabular}{llll}
\hline & & & sional \\
\hline $\begin{array}{l}\text { Gross } \\
\text { Revenue }\end{array}$ & Juta Rp & 6,82 & 1,22 \\
$\begin{array}{l}\text { Nett in- } \\
\text { come }\end{array}$ & Juta Rp & 2,85 & 0,22 \\
$\%$ Profit & $\%$ & $72 \%$ & $22 \%$ \\
\hline
\end{tabular}

\section{KESIMPULAN}

Transfer teknologi bioflok pada pembudi daya ikan dapat diterima dan diserap dengan baik

Produksi budi daya lele system bioflok rata-rata $568 \mathrm{Kg}$.

Usaha budi daya lele sistem bioflok mampu menghasilkan keuntungan bersih hingga Rp. 2.850.000,-.

\section{UCAPAN TERIMA KASIH}

Penulis mengucapkan terima kasih kepada DP2M Dikti yang telah membiayai kegiatan ini melalui skema Iptek bagi Masyarakat (IbM) tahun 2013, Pokdakkan Mina Rawa Mas dan Mina Lancar serta LPPM Unsoed yang telah memfasilitasi kegiatan ini hingga berjalan lancar.

\section{DAFTAR PUSTAKA}

Affandi, R. (2004). Fisiologi Pencernaan Ikan. IPB Press. Bogor.

Avnimelech, Y. (2007). Feeding with microbial flocs by tilapia in minimal discharge bio-flocs technology ponds. Aquaculture 264: 140-147

Anvimelech,Y. \& Kochba. (2009). Evaluation of nitrogen uptake and axcretion by tilapia in bio floc tanks, us- ing $15 \mathrm{~N}$ tracing. Aquaculture 287: 163-168

Ekasari, J. (2009). Teknologi Bioflok : Teori dan Aplikasi dalam perikanan budi daya system intensif. Jurnal Akuakultur Indonesia 8 (2) : 117226.

Hernawati, \& Suantika, G. (2007). Penggunaan Sistem Resirkulasi Dalam Pendederan Benih Ikan Gurami. Jurnal DiSainTek Vol. 01, No. 01.

Sarwono, \& Agustina. (2002). Pengaruh padat penebaran terhadap laju nitrifikasi dalam budi daya ikan sistem resirkulasi tertutup. Jurnal Akuakultur Indonesia 1(2): 47-51 